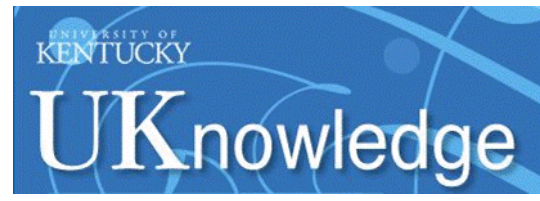

University of Kentucky UKnowledge

$6-2005$

\title{
Manganese Distribution across the Blood-Brain Barrier. IV. Evidence for Brain Influx through Store-Operated Calcium Channels
}

Janelle S. Crossgrove

University of Kentucky

Robert A. Yokel

University of Kentucky, ryokel@email.uky.edu

Right click to open a feedback form in a new tab to let us know how this document benefits you. Follow this and additional works at: https://uknowledge.uky.edu/ps_facpub

Part of the Pharmacy and Pharmaceutical Sciences Commons, and the Toxicology Commons 


\section{Manganese Distribution across the Blood-Brain Barrier. IV. Evidence for Brain Influx through Store-Operated Calcium Channels}

Digital Object Identifier (DOI)

https://doi.org/10.1016/j.neuro.2004.09.004

Notes/Citation Information

Published in Neurotoxicology, v. 26, issue 3.

Copyright $\odot 2004$ Elsevier Inc.

(c) 2004. This manuscript version is made available under the CC-BY-NC-ND 4.0 license

https://creativecommons.org/licenses/by-nc-nd/4.0/.

The document available for download is the authors' post-peer-review final draft of the article. 
MANGANESE DISTRIBUTION ACROSS THE BLOOD-BRAIN BARRIER

IV. EVIDENCE FOR BRAIN INFLUX THROUGH STORE-OPERATED CALCIUM

\section{CHANNELS}

Janelle S. Crossgrove ${ }^{1,2}$ and Robert Yokel ${ }^{1,3}$

${ }^{1}$ Graduate Center for Toxicology, University of Kentucky Medical Center, Lexington, KY, 40536-0305, 2Present address: School of Health Sciences, Purdue University, West Lafayette, IN, 47907 and ${ }^{3}$ College of Pharmacy, University of Kentucky Medical Center, Lexington, KY, 40536-0082.

Robert Yokel

511C Pharmacy Building

University of Kentucky

907 Rose Street

Lexington, KY 40536-0082

Phone: (859) 257-4855

Fax: (859) 323-6886

E-mail: ryokel@email.uky.edu 


\section{ABSTRACT}

Manganese $(\mathrm{Mn})$ is a required co-factor for many ubiquitous enzymes; however, chronic manganese overexposure can cause manganism, a parkinsonian-like syndrome. Previous studies showed manganese influx into brain is carrier-mediated, though the putative carrier(s) were not established. Studies conducted with cultured bovine brain microvascular endothelial cells (bBMECs), which comprise the bloodbrain barrier, revealed ${ }^{54} \mathrm{Mn}$ (II) uptake positively correlated with $\mathrm{pH}$, was temperature-dependent, and was sodium- and energy-independent. Brain ${ }^{54} \mathrm{Mn}$ uptake correlated inversely with calcium (Ca) concentration, but ${ }^{45} \mathrm{Ca}$ uptake was unaltered by high Mn concentration. Lanthanum (La), a non-selective inhibitor of several Ca channel types, as well as verapamil and amiloride, inhibitors of voltageoperated Ca channels, failed to inhibit Mn uptake into cells. Nickel (Ni), another nonselective inhibitor of several Ca channel types, inhibited Mn and Ca uptake into cells by 88 and $85 \%$, respectively. Cyclopiazonic acid (CPA) and thapsigargin, which activate store-operated calcium channels (SOCCs), increased ${ }^{54} \mathrm{Mn}$ and ${ }^{45} \mathrm{Ca}$ uptake into cultured bBMECs. In situ brain perfusion studies were conducted in adult, male Sprague-Dawley rats to verify the cell culture results. Both nickel and verapamil produced a non-significant decrease in $\mathrm{Mn}$ and $\mathrm{Ca}$ influx. Lanthanum significantly increased Mn influx to 675 and $450 \%$ of control in parietal cortex and caudate, respectively, while producing no significant effect on Ca influx. Vanadate, which inhibits Ca-ATPase, inhibited Mne uptake into cultured blood-brain barrier cells, but not into perfused rat brain. Overall these results suggest that both Ca-dependent and $\mathrm{Ca}$-independent mechanisms play a role in brain $\mathrm{Mn}$ influx. This work provides 
evidence that store-operated Ca channels, as well as another blood-brain barrier transporter, are likely to mediate carrier-mediated $\mathrm{Mn}$ influx into the brain.

Running title: Mn brain influx at the BBB through SOCs

Key words/phrases: manganese, blood-brain barrier, influx, store-operated calcium channel 


\section{INTRODUCTION}

The trace element manganese $(\mathrm{Mn})$ is essential for normal brain development and function throughout the life span of all mammals (Keen et al., 2000). Mn is a cofactor for many enzymes, including the brain-specific enzyme glutamine synthetase (Wedler and Denman, 1984) and ubiquitously expressed enzymes including superoxide dismutase 2 and pyruvate carboxylase (Keen, et al., 2000). While Mn is essential for normal brain function, excess brain $\mathrm{Mn}$ is neurotoxic and can produce manganism, a parkinsonian-like syndrome (Hudnell, 1999; Iregren, 1999).

Neurotoxicity due to excess $\mathrm{Mn}$ has been reported following occupational inhalation exposure to $\mathrm{Mn}$ in mining operations (Couper, 1837), in dry-cell battery production (Keen and Lönnerdal, 1995), in ferromanganese smelting (Huang et al., 1989) and during Mn welding operations (Chandra et al., 1981; Ono et al., 2002); following nonoccupational exposure to inhaled Mn (Hudnell, 1999) and following intestinal exposure of $\mathrm{Mn}$ in drinking water. There is currently significant concern about airborne Mn exposure from the fuel additive methylcyclopentadienyl manganese tricarbonyl (MMT) (Hudnell, 1999). Current treatments for patients with manganism may postpone the progression of symptoms, but have not been able to cure the disease (reviewed in (Lee, 2000).

As the general public's Mn exposure increases with increased MMT use, the mechanisms of $\mathrm{Mn}$ homeostasis become more important in understanding and assessing the risk of neurotoxicity. Mn brain entry from blood can occur through the capillary endothelial cells of the blood-brain barrier (BBB) and through the choroid 
plexuses. Several studies suggested that $\mathrm{Mn}$ ion brain influx at the BBB is carriermediated (Aschner and Aschner, 1990; Murphy et al., 1991; Rabin et al., 1993; Aschner and Gannon, 1994; Crossgrove et al., 2003). Similarly, Mn appears to be actively transported into bile, achieving a concentration gradient as high as 100 -fold (Klaassen, 1974). The identity of the Mn carrier(s) is unknown. Mn efflux across the BBB does not appear to occur through a carrier but rather by diffusion (Yokel et al., 2003). Several studies suggested that the divalent metal transporter-1 (DMT-1) may be responsible for Mn ion influx into brain (Goddard et al., 1997; Gunshin et al., 1997; Conrad et al., 2000), but a recent report suggests that the lack of functional DMT-1 in rats has no effect on brain influx of the Mn ion or the Mn-transferrin complex (Crossgrove and Yokel, 2004).

The current work examined whether brain $\mathrm{Mn}$ influx at the BBB is mediated by one or more calcium (Ca) transport pathways. Ca inhibited Mn entry into Hep-G2 cells (Finley, 1998). Cell Mn entry across cell membranes was decreased by Ca inhibitors (Mason et al., 1993) and increased by activators of Ca influx (Kerper and Hinkle, 1997a). Mn entry through store-operated Ca channels (SOCs) has been demonstrated in rat mast and osteoblast-like cells and human platelets (Fasolato et al., 1993; Dobrydneva and Blackmore, 2001; Baldi et al., 2002). Others have reported evidence of SOCs on brain endothelial cells (Kerper and Hinkle, 1997b; Kim et al., 2004). In this work, we examined the mechanism(s) of Mn brain entry across the BBB. We first examined general characteristics of Mn uptake at the BBB 
BBB Mn influx through SOCs 6

and then tested the hypothesis that Mn influx at the BBB occurs through one or more Ca influx processes.

\section{MATERIALS AND METHODS}

\section{Materials}

${ }^{54} \mathrm{MnCl}_{2}$ (specific activity 107 or $38 \mathrm{nCi} / \mathrm{ng}$; total $\mathrm{Mn} 184$ or $477 \mathrm{nM}$ ) in $0.5 \mathrm{M} \mathrm{HCl}$ was purchased from Perkin-Elmer/NEN (Boston, MA). ${ }^{45} \mathrm{CaCl}_{2}(5.87 \mathrm{nCi} / \mathrm{ng})$ in water was purchased from Perkin-Elmer/NEN. $\left[{ }^{14} \mathrm{C}\right]$ sucrose was purchased dry from PerkinElmer/NEN (3.6 nCi/nmol) and in 2\% ethanol from Moravek (Brea, CA; 495 $\mathrm{nCi} / \mathrm{nmol})$ or American Radiolabeled Chemicals, Inc. (620 nCi/nmol). All other chemicals were purchased from Sigma (St. Louis, MO) unless otherwise noted. Sprague-Dawley rats (225-300 g) were purchased from Harlan (Indianapolis, IN). Verapamil was solubilized in methanol, diluted and delivered in $0.2 \%$ methanol. Thapsigargin was solubilized by DMSO and cyclopiazonic acid by methanol and delivered in $0.1 \%$ DMSO or methanol. Vehicle controls contained equimolar solvent. All animal research was conducted under the guidelines of the Guide for the Care and Use of Laboratory Animals and with the approval of the University of Kentucky Institutional Animal Care and Use Committee.

\section{Isolation of bovine brain microvascular endothelial cells (bBMECs)}

The bBMECs were isolated from fresh bovine brains, as described (Bowman et al., 1983; Audus et al., 1996). Cells were grown in $35 \mathrm{~mm}$ plastic dishes at $37^{\circ} \mathrm{C}$ in $5 \%$ $\mathrm{CO}_{2}$ with nutrient media containing $10 \%$ horse serum in $50 \%$ MEM and $50 \%$ Ham's 
F-12 supplemented with $\mathrm{NaHCO}_{3}(13 \mathrm{mM})$, HEPES $(10 \mathrm{mM})$ penicillin $\mathrm{G}(100 \mathrm{U} / \mathrm{mL})$ and streptomycin $(100 \mu \mathrm{g} / \mathrm{ml})$. Cell identity was verified by the presence of the following characteristics of bBMECs. 1.) They were positive for $y$ glutamyltransferase and alkaline phosphatase activity. 2.) They did not have the processes or shapes of neurons or glial cells according to morphologic analysis of TEM images. 3.) They took up histidine (Yamakami et al., 1998).

\section{Studies of ${ }^{54} \mathrm{Mn}$ uptake conducted in bBMECs}

${ }^{54} \mathrm{Mn}$ uptake was determined in $85-90 \%$ confluent cell cultures following procedures established for another BBB cell line (Yokel et al., 2002). In summary, each cellcontaining culture dish was rinsed three times with a wash solution containing (in $\mathrm{mM}): \mathrm{Na}^{+} 122, \mathrm{~K}^{+} 4.2, \mathrm{Ca}^{2+} 1.5, \mathrm{Mg}^{2+} 0.9, \mathrm{Cl}^{-} 131, \mathrm{HEPES} 10$, and D-glucose 10 at $\mathrm{pH} 7.4$ and at the temperature of the uptake experiment. The last wash remained in the dish at least 10 minutes to bring the cells to the temperature of the uptake experiment. The cells were incubated with $0.75 \mathrm{~mL}$ uptake solution consisting of wash solution containing ${ }^{54} \mathrm{Mn}^{2+}(\sim 1 \mu \mathrm{Ci} / \mathrm{mL})$ and $\left[{ }^{14} \mathrm{C}\right]$-sucrose $(1 \mu \mathrm{Ci} / \mathrm{mL} ; 0.2 \mu \mathrm{M})$ in the presence or absence of treatment. After 10 to 120 minutes the uptake solution was removed and the cells rapidly washed 5 times with ice-cold wash solution. Cells were solubilized in $1 \mathrm{M}$ sodium hydroxide for $15 \mathrm{~min}$ at room temperature then neutralized with equimolar $\mathrm{HCl}$. Aliquots of cell lysates were collected for analysis of radioactivity and total protein content. 
Cell viability was measured in parallel dishes of cultured bBMECs exposed to the same treatments in the absence of the radionuclides. Cell membrane integrity was measured by determining the activity of the cytosolic enzyme lactate dehydrogenase $(\mathrm{LDH})$ released into the uptake media. LDH activity was measured with an assay kit (Sigma). Cell redox potential, an indicator of cell health, was measured by methylthiazoletetrazolium (MTT) conversion to its formazan product. When MTT conversion was less than $80 \%$ of control the cells were considered to have drastically changed. Data from these cells were not used (except in studies of metabolic inhibitors and low temperature).

bBMECs were selected as a model of the BBB to screen characteristics of Mn uptake, with the intent of following significant findings in the intact rat. Initially, Mn uptake into bBMECs was measured from 10-120 minutes at $\mathrm{pH} 6.4$ and 7.4 to determine whether it was linear, as several pHs were used in subsequent studies. ${ }^{54} \mathrm{Mn}^{2+}$ uptake over 30 minutes was measured in media buffered to $\mathrm{pH} 5.4,6.4,6.9,7.4$ and 7.9 by $10 \mathrm{mM}$ potassium hydrogen phthalate $(\mathrm{pH} 5.4)$, PIPES (pH 6.4), MOPS (pH 6.9), or HEPES ( $\mathrm{pH} 7.4$ and 7.9). Mn uptake was also measured during a 30 minute incubation at 4 (on ice), $8,21,30$ and $37^{\circ} \mathrm{C}$; at $37^{\circ} \mathrm{C}$ in the presence of a metabolic inhibitor, 2,4-dinitrophenol $(0.25 \mathrm{mM})$ or azide $(10 \mathrm{mM})$; and with the replacement of glucose $(10 \mathrm{mM})$ by 2-deoxyglucose $(10 \mathrm{mM})$. The role of sodium in Mn uptake was measured by replacing 50 or $100 \%$ of the sodium in the uptake media with choline or lithium or by the addition of ouabain $(0.1 \mathrm{mM})$. The role of Ca transporters in $\mathrm{Mn}$ uptake was examined by changing Ca concentration from 0 to $1.5 \mathrm{mM}$; by addition 
of Ca transporter inhibitors including vanadate $(0,0.003$, or $1 \mathrm{mM})$, lanthanum $\left(\mathrm{La}^{3+}\right.$; $0.050 \mathrm{mM}$ as $\left.\mathrm{La}\left(\mathrm{NO}_{3}\right)_{3}\right)$, nickel $\left(\mathrm{Ni} ; 1 \mathrm{mM}\right.$ as $\left.\mathrm{NiCl}_{2}\right)$ or verapamil $(0.3 \mathrm{mM})$; or by addition of the Ca transporter activators cyclopiazonic acid (CPA; $0.01 \mathrm{mM})$ and thapsigargin $(0.001 \mathrm{mM})$.

\section{In situ brain perfusion studies}

Rats were prepared and perfused as described previously (Crossgrove, et al., 2003). Briefly, a cannula containing heparinized saline was inserted into the right common carotid artery. The open end was transferred to a syringe containing a perfusate with the treatment and/or radioisotope tracers. Perfusate delivery was regulated by a syringe pump. Immediately before brain perfusion began, the rat's cardiac ventricles were severed to avoid mixing of blood with perfusate. The perfusion $(45,90$ or 180 s) was terminated by decapitation. The brain was extracted and the ipsilateral parietal cortex, caudate and lateral ventricular choroid plexus removed, weighed and assayed for radioactivity. In some experiments, the cerebrum was homogenized according to the capillary depletion method as described (Crossgrove, et al., 2003).

The perfusate contained 1 to $2 \mu \mathrm{Ci}{ }^{54} \mathrm{Mn}^{2+} / \mathrm{ml}$ and a marker for vascular and extracellular space, ${ }^{14} \mathrm{C}$-sucrose $(1 \mu \mathrm{Ci} / \mathrm{ml})$, in a solution containing (in $\left.\mathrm{mM}\right): \mathrm{Na}^{+}$ 122, $\mathrm{K}^{+} 4.2, \mathrm{Ca}^{2+} 1.5, \mathrm{Mg}^{2+} 0.9, \mathrm{Cl}^{-} 131$, glucose 10 , and HEPES 10. To test the hypothesis that $\mathrm{Mn}$ and $\mathrm{Ca}$ share one or more transporters, rats were treated with perfusates containing ${ }^{54} \mathrm{Mn}^{2+}$ and 0 added, 1.5 (control) or $9 \mathrm{mM} \mathrm{Ca}$ or ${ }^{45} \mathrm{Ca}$ and $\mathrm{Mn}$ ( 0 or $15 \mathrm{mM}$ ). Other experiments included the Ca transporter inhibitors sodium 
vanadate (1 or $10 \mathrm{mM}), p$-hydroxyhippuric acid $(0.4 \mathrm{mM})$, verapamil $(0.3 \mathrm{mM})$ or amiloride $(0.84 \mathrm{mM})$ to determine whether $\mathrm{Ca}$ transporters play a role in rat brain $\mathrm{Mn}$ influx.

\section{Radioactivity and total protein determination}

Radioactivity of ${ }^{54} \mathrm{Mn}$ and ${ }^{14} \mathrm{C}$ were determined in aliquots of cell lysate or in digested tissue as described (Crossgrove, et al., 2003). Radioactivity from ${ }^{45} \mathrm{Ca}$ was counted from 156-257 keV by a liquid scintillation counter, with appropriate corrections for crossover, quench and decreased efficiency due to the narrowed counting window. Protein concentration in cell lysates was measured via the bicinchoninic acid method with a kit (Sigma).

\section{Data and statistical analysis}

In bBMEC experiments, ${ }^{54} \mathrm{Mn},{ }^{45} \mathrm{Ca}$ and ${ }^{14} \mathrm{C}$ activities (dpm/dish) and total protein (mg/dish) were calculated. ${ }^{54} \mathrm{Mn},{ }^{45} \mathrm{Ca}$ and $\left[{ }^{14} \mathrm{C}\right]$-sucrose uptake values were converted to $\mathrm{dpm} / \mathrm{mg}$ protein. Non-specific binding to cell and collagen surfaces was determined by apparent uptake in $15 \mathrm{~s}$ on ice. Collagen was found to sequester $\mathrm{Mn}$, but not ${ }^{14} \mathrm{C}$ or ${ }^{45} \mathrm{Ca}$, during the time course of these experiments. Estimated confluence was used to predict the surface area of the collagen-coated dish that was exposed to ${ }^{54} \mathrm{Mn}$ uptake media. Uptake into collagen was determined as:

Mn uptake into collagen $=(100 \%-\text { confluence } \%)^{*}($ uptake into collagen-only dish $)$ 
Nonspecific Mn adsorption to the dish was also determined several times. It was negligible. Non-specific binding and estimated binding to collagen were subtracted from total uptake to obtain corrected values for ${ }^{54} \mathrm{Mn},{ }^{45} \mathrm{Ca}$, and ${ }^{14} \mathrm{C}$ uptake into cells. These corrected values ( $\mathrm{dpm} / \mathrm{mg}$ protein) were divided by the activity of the uptake solution $(\mathrm{dpm} / \mathrm{ml})$ to obtain a volume of distribution of uptake $(\mathrm{ml} / \mathrm{mg}$ protein) from uptake media.

The $\left[{ }^{14} \mathrm{C}\right]$-sucrose volume represents diffusional and pinocytotic uptake processes. This value was subtracted from the ${ }^{54} \mathrm{Mn}$ and ${ }^{45} \mathrm{Ca}$ volumes of distribution to generate a term expressing $\mathrm{Mn}$ or Ca uptake into the cells via carrier(s). Mn uptake ( $\mathrm{ml} / \mathrm{mg}$ protein) was converted to $\mathrm{pmol} \mathrm{Mn} / \mathrm{mg}$ protein by multiplying by total $\mathrm{Mn}$ concentration. Intracellular Mn concentration was then estimated from the relationship of $2 \mu \mathrm{l}$ intracellular space per mg total protein (Edlund and Halestrap, 1988; Poole et al., 1989).

In perfusion experiments, radioactivity (dpm/g tissue) was divided by perfusate activity $(\mathrm{dpm} / \mathrm{ml})$ to calculate the volume of distribution $(\mathrm{ml} / \mathrm{g})$. This was divided by the perfusion duration (45 to $90 \mathrm{~s}$ ) to obtain the influx transfer coefficient (Kin), as described in detail (Crossgrove, et al., 2003). All bBMEC experiments were completed with at least three replicates per experiment, each conducted in duplicate or triplicate. Results of the time course of $\mathrm{Mn}$ uptake at $\mathrm{pH} 6.4$ and 7.4 were analyzed by regression analysis using GraphPad Prism to determine if uptake was best fit by a first or second order relationship. Uptake in the presence of treatments 
was converted to a percent of control uptake for each experiment. The mean and relative standard deviation were calculated. For cell and perfusion experiments, ttests or one-way ANOVAs were conducted using GraphPad Prism to test for treatment differences. When treatment differences were found, post-hoc comparisons by Dunnett's or Bonferroni's tests were conducted after the ANOVAs to determine significant differences among treatment groups.

For all studies, $p<0.05$ was accepted as statistically significant.

\section{RESULTS}

${ }^{54} \mathrm{Mn}$ uptake into bBMECs was initially studied up to 120 minutes to assess linearity during that time (Figure 1 Inset). Regression analysis showed Mn uptake results obtained at $\mathrm{pH} 7.4$ and 6.4 were better fit by linear than non-linear regression. The $95 \%$ confidence intervals for the slopes excluded one another. $\mathrm{Mn}^{2+}$ uptake at $\mathrm{pH}$ 6.4 was significantly less than at 7.4. For the remaining studies, 30-minute uptake was used as representative.

At the 120 minute time point, the intracellular Mn concentration (overall means of 10.6 and $3.4 \mu \mathrm{M}$ for $\mathrm{pH} 7.4$ and 6.4 , respectively), exceeded the media $\mathrm{Mn}$ concentration (184 $\mathrm{nM})$ by at least 10 fold. In later experiments using ${ }^{54} \mathrm{Mn}$ at a lower specific activity and higher total Mn (477 vs. $184 \mathrm{nM})$, the intracellular concentration at 30 minutes was at least 3-fold, and usually 10 -fold, greater than the extracellular 
concentration. Intracellular Mn concentration was higher than extracellular Mn concentration in all experiments under control conditions.

Mn uptake was inversely related to proton concentration. This was noted in the time course of Mn uptake conducted at pH 6.4 and 7.4 as well as the uptake study conducted at $\mathrm{pH} 5.4,6.4,6.9,7.4$ and 7.9 (Figure 1). The results from cells treated at $\mathrm{pH} 5.4$ for 30 minutes are not shown because they produced only $6 \%$ of the formazan product/mg protein that was found in control $(\mathrm{pH} 7.4)$ cells, indicating severe cell toxicity.

\section{Temperature-dependence of uptake}

Mn uptake into bBMECs was measured at five temperatures. The data were graphed as an Arrhenius plot of natural log of the uptake rate versus inverse of absolute temperature (Figure 2). The plot appears to have a change in slope (a breakpoint); however, the data are not significantly non-linear. Rearrangement of the Arrhenius equation, as follows, generated the activation energy ( $\left.E_{a}\right)$.

$$
E_{a}=-R^{*}(d \ln \mathrm{k}) / d(1 / \mathrm{T})
$$

where $\mathrm{R}$ is the ideal gas constant, $\mathrm{k}$ is the uptake rate and $d(\ln \mathrm{k}) / d(1 / \mathrm{T})$ is the slope of Figure 2. $\mathrm{E}_{\mathrm{a}}$ was determined to be $27 \mathrm{~kJ} / \mathrm{mol}$. 


\section{Sodium- and energy-independence of uptake}

Mn uptake into bBMECs was not inhibited by replacement of the sodium in the uptake medium (Table 1). Sodium replacement by choline resulted in a significant increase of Mn uptake into bBMECs. Energy production inhibitors reduced MTT conversion to formazan by $\sim 40 \%$ (results not shown) but did not significantly affect Mn uptake into bBMECs (Table 1).

\section{Calcium-dependence of bBMEC uptake and brain influx}

There was an inverse relationship between Ca concentration and brain Mn influx (Figure 3) as well as Mn uptake and Ca concentration in bBMECs (Table 2). However, Mn did not inhibit brain Ca influx (Figure 3).

$\mathrm{La}^{3+}$ increased brain Mn influx (Figure 4), and Ni did not decrease Mn influx into rat brain (Figure 5). Verapamil did not significantly inhibit Mn influx compared to control. Mean Mn influx values \pm SEM $(n=5-6)$ for control versus verapamil were $20.6 \pm 2.7$ vs. $14.9 \pm 1.6 ; 12.4 \pm 2.5$ vs. $6.6 \pm 0.4$; and $1218 \pm 108$ vs. $863 \pm 62 \times 10^{-5} \mathrm{ml} / \mathrm{s} / \mathrm{g}$ for parietal cortex, caudate or choroid plexus, respectively. Another voltage-gated $\mathrm{Ca}$ channel inhibitor, amiloride, did not inhibit brain Mn influx (Ca was not tested). Mn influx values for control versus amiloride-treated brains were $6.2 \pm 2.2$ vs. $11.3 \pm 5.7$; $6.7 \pm 0.7$ vs. $4.7 \pm 1.6 ; 2197 \pm 421$ vs. $1756 \pm 178 \times 10^{-5} \mathrm{ml} / \mathrm{s} / \mathrm{g}$ for the parietal cortex, caudate or choroid plexus, respectively (mean \pm SEM of 4 control and 3 treated brains). 
Brain Ca influx was measured concurrently with $\mathrm{Mn}$ influx for control perfusates and those with La, Ni or verapamil. Control Ca influx values (mean \pm SEM, $n=5-6$ ) were $85.1 \pm 15.7,61.4 \pm 11$ and $873 \pm 177 \times 10^{-5} \mathrm{ml} / \mathrm{s} / \mathrm{g}$ for parietal cortex, caudate and choroid plexus, respectively. Ca influxes with La were $75 \pm 22.9,55.1 \pm 27.2$ and $672 \pm 145 \times 10^{-5} \mathrm{ml} / \mathrm{s} / \mathrm{g}$. Ca influx with Ni were $62.1 \pm 18.5 ; 39.6 \pm 10 ;$ and $1058 \pm$ $497 \times 10^{-5} \mathrm{ml} / \mathrm{s} / \mathrm{g}$ for parietal cortex, caudate and choroid plexus, respectively; with verapamil, $80.4 \pm 10.5 ; 54.7 \pm 7.5$; and $922 \pm 182 \times 10^{-5} \mathrm{ml} / \mathrm{s} / \mathrm{g}$. Brain Ca influx was not significantly affected by any of these treatments within this short time course.

$\mathrm{La}^{3+}$ decreased Ca uptake into bBMECs without having a significant effect on $\mathrm{Mn}$ uptake (Table 2). Ni significantly inhibited $\mathrm{Ca}$ and Mn uptake into bBMECs (Table 2). In addition to its effect on brain influx, verapamil also produced parallel, nonsignificant decreases of Mn and Ca uptake into bBMECs (Table 2).

Vanadate $(1 \mathrm{mM})$ did not significantly inhibit $\mathrm{Mn}$ influx into the tested brain regions or the choroid plexus following its co-perfusion with ${ }^{54} \mathrm{Mn}^{2+}$ for 90 seconds. Mean values \pm SEM (4 rats per group) were $49.2 \pm 21.1$ vs. $51.2 \pm 23.8,7.4 \pm 2.8$ vs. 17.0 \pm 10.5 and $759 \pm 347$ vs. $450 \pm 190 \times 10^{-5} \mathrm{ml} / \mathrm{s} / \mathrm{g}$ for control vs. vanadate-treated parietal cortex, caudate and choroid plexus tissues. When the brain was perfused with $1 \mathrm{mM}$ vanadate for $90 \mathrm{~s}$ and then immediately switched to a co-perfusion of vanadate with ${ }^{54} \mathrm{Mn}^{2+}, \mathrm{Mn}$ influx was not inhibited by the vanadate pre-wash exposure. The control and vanadate-treated brain Mn influx values were $4.4 \pm 0.9$ 
vs. $16.4 \pm 7.7,2.6 \pm 0.7$ vs. $4.0 \pm 0.7$ and $247 \pm 35$ vs. $746 \pm 53 \times 10^{-5} \mathrm{ml} / \mathrm{s} / \mathrm{g}$ for the parietal cortex, caudate and choroid plexus regions of the brain, respectively (mean \pm SEM for 6 rats per group). A higher concentration of vanadate $(10 \mathrm{mM})$ also failed to inhibit brain $\mathrm{Mn}$ influx. The parietal cortex, caudate and choroid plexus Mn influx values were $13.4 \pm 4.4$ vs. $21.5 \pm 6.6,7.4 \pm 1.6$ vs. $11.4 \pm 4.1$ and $1063 \pm 294$ vs $1376 \pm 318 \times 10^{-5} \mathrm{ml} / \mathrm{s} / \mathrm{g}$ brain for control vs. vanadate-treated brain, respectively (mean \pm SEM for 5 rats per group). Vanadate did not change the distribution of Mn in the endothelial cells or the brain parenchyma. Endothelial cells retained 10 and $13 \%$ of the total Mn entering brain following perfusion with $\mathrm{Mn}$ or $\mathrm{Mn}$ with vanadate (10 mM; data not shown). Therefore, brain parenchyma contained 90 and $87 \%$ of the Mn that had crossed the BBB.

Contrary to in situ perfusion results, addition of $3 \mu \mathrm{M}$ or $1 \mathrm{mM}$ vanadate inhibited $\mathrm{Mn}$ uptake into bBMECs (Table 2). Furthermore, this effect persisted after vanadate was washed out. Cells treated 30 minutes with $1 \mathrm{mM}$ vanadate, washed twice and incubated with vanadate-free uptake media had only $39 \%$ of control Mn uptake (Table 2).

Addition of $p$-hydroxyhippuric acid $(0.4 \mathrm{mM})$ to the brain perfusate did not inhibit brain $\mathrm{Mn}$ influx (Ca influx was not tested). The control and experimental brain $\mathrm{Mn}$ influx values were $7.4 \pm 0.6$ vs. $12.7 \pm 1.8,8.6 \pm 1.4$ vs. $6.7 \pm 0.6$ and $1375 \pm 100$ vs $1310 \pm 122 \times 10^{-5} \mathrm{ml} / \mathrm{s} / \mathrm{g}$ for the parietal cortex, caudate and choroid plexus, respectively (mean \pm SEM for 6 control and 7 treated rats). In the cerebellum only, 
there was a non-significant trend for a $p$-hydroxyhippuric acid-induced decrease of Mn influx (11.0 \pm 1.9 vs. $5.7 \pm 0.6 \times 10^{-5} \mathrm{ml} / \mathrm{s} / \mathrm{g}$ for control vs. $p$-hydroxyhippurate $)$.

\section{Studies with modulators of store-operated Ca channels}

CPA significantly increased $\mathrm{Mn}$ and Ca uptake when studied concurrently (Table 2). Ca uptake following thapsigargin treatment was not significantly greater than control $(P=0.07)$, although Ca uptake in thapsigargin-treated cells was $1.4-10$ fold greater than in control cells in each experimental replicate. Mn uptake was significantly greater in thapsigargin-treated than in control cells (Table 2).

\section{DISCUSSION}

This research examined the mechanism of carrier-mediated Mn entry into the rat brain across the BBB. The first objective was to determine general characteristics of carrier-mediated Mn uptake. The second objective tested the hypothesis that brain Mn entry was mediated by one or more Ca transporters. The results suggest that brain $\mathrm{Mn}$ influx occurs through at least one pathway which is not Ca-mediated as well as one or more pathways involving SOCs.

Our results are consistent with previous reports of carrier-mediated Mn uptake at the BBB (Aschner and Aschner, 1990; Murphy, et al., 1991; Rabin, et al., 1993; Aschner and Gannon, 1994; Crossgrove, et al., 2003). Here, we report concentrative Mn uptake, providing evidence of a carrier-mediated process. The temperaturedependence study suggests that the activation energy of this process is $27 \mathrm{~kJ} / \mathrm{mol}$, consistent with values reported for ion channels $(18-34 \mathrm{~kJ} / \mathrm{mol})$ by 
electrophysiological techniques (Liu et al, 1996). This supports the suggestion that brain Mn uptake occurs through one or more carrier-mediated processes. Finally, the negative correlation between proton concentration and Mn uptake into bBMECs agrees with our report that $\mathrm{Mn}$ uptake is not likely to occur through the divalent metal transporter-1, which co-transports a proton with a divalent metal ion (Crossgrove and Yokel, 2004).

Brain Mn uptake was not inhibited by 2,4-dinitrophenol, azide or 2-deoxyglucose, suggesting it is not directly dependent on an energy source mediated by ATP hydrolysis. Nor was brain Mn uptake inhibited by ouabain, showing it to be independent of $\mathrm{Na}^{+} / \mathrm{K}^{+}$-ATPase. While these studies did not provide evidence for energy dependence, the concentrative uptake seen in the bBMEC studies must rely on an energy source or electron transfer. The conversion of MTT to formazan in treated cells was $\sim 60 \%$ of control cells, suggesting reduction, but not elimination, of cell redox potential when ATP-inhibitors were present. Therefore, the lack of effect by metabolic inhibitors may be due either to the lack of an ATP-dependent Mn transporter or to the ability of the ATP-dependent Mn transporter(s) to continue at their normal rate when ATP is reduced to $60 \%$. Alternatively, the $\mathrm{pH}$ dependence suggests that there might be an electromotive driving force maintaining Mn uptake. However, the positive correlation between $\mathrm{Mn}$ uptake and $\mathrm{pH}$ suggest that it is not an inward proton or cation electromotive force. This suggests that the Mn transporter may be a proton or cation antiporter. 
Brain Mn uptake was sodium-independent, suggesting the uptake carrier(s) do not utilize a sodium gradient as a driving force. Replacing sodium with choline increased brain Mn uptake. One report provides evidence that $\mathrm{Mn}$ inhibits choline uptake at the BBB (Lockman et al., 2001). The authors suggested that the choline transporter may be involved in brain Mn uptake, though they did not test the effect of choline on $\mathrm{Mn}$ uptake. Choline uptake into rat brain, like Mn uptake, has been described to be sodium-independent (Allen and Smith, 2001). Mn and choline may share one or more transport process(es). On the other hand, choline increased Mn uptake, which would not be expected if they were competing for an uptake process. While the basis of any interaction between Mn and choline is unclear, it is clear that Mn uptake at the BBB is sodium independent.

Ca appears to play a significant role in Mn influx at the BBB. When Ca was not added to the perfusate, $\mathrm{Mn}$ influx was significantly greater than in the presence of normal (1.5 mM) Ca. Brain Mn influx was slightly, but not significantly, less in the presence of $9 \mathrm{mM} \mathrm{Ca}$. Ca has been shown to inhibit Mn uptake into astrocytes in competitive and non-competitive manners (Aschner et al., 1992). Mn uptake into bBMECs also increased in the absence of added Ca compared to uptake media with normal (1.5 mM) Ca. Overall, Ca concentration correlates negatively with Mn influx. This concentration-dependent effect does not distinguish whether $\mathrm{Ca}$ and $\mathrm{Mn}$ directly compete for the same carrier or whether $\mathrm{Ca}$ indirectly modulates Mn uptake. On the other hand, added $\mathrm{Mn}$ did not inhibit ${ }^{45} \mathrm{Ca}$ influx into rat brain compared to control (no added $\mathrm{Mn}$ ) perfusate (Figure 3), suggesting $\mathrm{Mn}$ and Ca do not compete 
for the same carrier, or that the capacity of any common carrier(s) is very large. Depending on the affinity of the Ca carrier for $\mathrm{Mn}$, the 10 -fold greater concentration of $\mathrm{Mn}$ above that of $\mathrm{Ca}$ used in the present studies may not be sufficient to inhibit brain Ca influx. A 6-fold increase in Ca failed to significantly inhibit Mn influx, which suggests either that they have separate carriers or that their shared pathway(s) has a great substrate capacity.

Mn uptake into bBMECs was inhibited by $\mathrm{Ni}$, consistent with a role for $\mathrm{Ca}$ channels in Mn uptake. Ni has been shown to inhibit receptor-operated Ca channels and store-operated channels (Cui and Dannies, 1992; Kukkonen et al., 2001). Ni is thought to be a rather specific inhibitor of Ca channels, as it did not appear to be a substrate for the channels it blocks (Shibuya and Douglas, 1992; Jones and Sharpe, 1994). In the current study, Ni blocked Mn uptake (to $12 \%$ control) in bBMECs in a manner parallel to its effect on Ca uptake (15\% control), providing strong evidence that Mn uptake may occur through Ca uptake pathways. An alternative explanation is that $\mathrm{Ni}$ blocks equally two or more separate pathways for $\mathrm{Mn}$ and $\mathrm{Ca}$ uptake, rather than our suggestion of a common pathway. In perfusion studies, Ni failed to block $\mathrm{Mn}$ and $\mathrm{Ca}$ brain influx. The difference between the animal and bBMEC studies may be due to the shorter experimental duration of in situ brain perfusion (90 s) than bBMEC studies (30 min). The lack of brain Mn influx inhibition by Ni may be due to Ni's inability to block Ca influx. The animal data, therefore, do not reveal any information whether Mn and Ca share the same BBB carrier(s) that are inhibited by $\mathrm{Ni}$. 
Ni significantly inhibited choroid plexus Mn influx; however, it did not inhibit Ca influx into the choroid plexus. This suggests that $\mathrm{Mn}$ and Ca may have separate uptake mechanisms at this blood-cerebrospinal fluid interface. The choroid plexus is believed to be the main site of $\mathrm{Ca}$ influx into brain. If the choroid plexus is vital in maintaining Ca homeostasis as implicated (Murphy et al., 1989; Keep et al., 1999), then perhaps the carriers expressed at the choroid plexus have a stronger affinity for $\mathrm{Ca}$, rendering the $\mathrm{Ni}$ treatment an ineffective inhibitor of $\mathrm{Ca}$ influx. Alternatively, $\mathrm{Ni}$ may not have had sufficient time to inhibit Ca transporters, or the inhibition of $\mathrm{Mn}$ uptake into choroid plexus is independent of Ca transporters.

The results with the Ca transporter blocker, $\mathrm{La}^{3+}$, suggest that a non-Ca pathway also mediates brain $\mathrm{Mn}$ influx. $\mathrm{La}^{3+}$ inhibition of $\mathrm{Ca}$ uptake has been shown in voltage-gated $\mathrm{Ca}$ channels, receptor-operated $\mathrm{Ca}$ channels and store-operated $\mathrm{Ca}$ channels (Cui and Dannies, 1992; Davidson and Guo, 2000; Liu and Ambudkar, 2001; Wu et al., 2001). In perfusion studies, $\mathrm{La}^{3+}$ significantly increased Mn influx more than 4-fold. A literature search did not reveal any other reports of $\mathrm{La}^{3+}$ increasing transporter or carrier activity. There was no effect on brain Ca influx in the present studies, suggesting $\mathrm{La}^{3+}$ did not block $\mathrm{Ca}$ influx. Furthermore, the results suggest that the $\mathrm{La}^{3+}$ effect on Mn influx at the BBB is independent of Ca. In bBMEC studies, $\mathrm{La}^{3+}$ did not significantly affect $\mathrm{Mn}$ or Ca uptake. While rat studies indicated that $\mathrm{La}^{3+}$ increases $\mathrm{Mn}$, but not brain Ca influx, bBMEC studies suggested a nonsignificant decrease in $\mathrm{Mn}$ and $\mathrm{Ca}$ uptake. The results suggest that $\mathrm{Mn}$ uptake at the 
BBB also occurs through one or more Ca-independent processes, since $\mathrm{La}^{3+}$ increases Mn uptake without affecting Ca.

Another explanation for the unexpected increase in $\mathrm{Mn}$ uptake by $\mathrm{La}^{3+}$ is transstimulation of the endothelial cells. This process occurs when a substrate on one side of the cell membrane increases substrate transfer from the other side. transStimulation has been shown to play a role in the uptake of glucose into bovine mammary epithelial cells (Xiao and Cant, 2003), agmatine through the human extraneuronal monoamine transporter (Grundemann et al., 2003) and sorbitol into a renal medullary cell line (Schuttert et al., 2002). ${ }^{54} \mathrm{Mn}$ efflux from astrocytes was trans-stimulated by ${ }^{55} \mathrm{Mn}$ in the media (Aschner, et al., 1992). La ${ }^{3+}$ may enter cells rapidly and then cause greater $\mathrm{Mn}$ influx through trans-stimulation.

In bBMEC studies, Mn entry was inhibited by vanadate (0.003 and $1 \mathrm{mM})$. Despite indications in bBMECs, addition of 1 or $10 \mathrm{mM}$ vanadate to ${ }^{54} \mathrm{Mn}$ in the in situ brain perfusate did not decrease brain Mn influx. Ca-ATPases are found on both the luminal and abluminal surface of brain endothelial cells, which may confound our interpretation of the results (Manoonkitiwongsa et al., 2000). Mn distribution into endothelial and brain cell plus extracellular fluid fractions, as measured with the capillary depletion method, was unaltered by vanadate, suggesting neither brain $\mathrm{Mn}$ influx nor efflux are mediated by Ca-ATPase. Although vanadate inhibited Mn uptake into bBMECs, it did not inhibit Mn influx across the BBB. $p$-Hydroxyhippuric acid, a 
relatively selective Ca-ATPase inhibitor, also did not inhibit brain Mn influx, providing further evidence against a role for Ca-ATPase.

Studies with inhibitors of voltage-gated Ca channels also failed to implicate these channels in brain Mn uptake. This is not surprising, as endothelial cells are not considered excitable and would not be expected to use voltage-gated channels. On the other hand, it was recently determined that brain endothelial cells do express Ltype Ca channels (Bossu et al., 1992). Verapamil did not significantly decrease Mn or Ca influx. In a similar study in the absence of ${ }^{45} \mathrm{Ca}$, verapamil and amiloride failed to alter brain ${ }^{54} \mathrm{Mn}$ influx. These results suggest brain $\mathrm{Mn}$ entry is not likely to occur through voltage-gated Ca channels under physiological conditions.

Thapsigargin and CPA significantly increased Mn uptake, 2.5- and 2.6-fold, respectively, consistent with the hypothesis that SOCs play a role. Thapsigargin did not significantly increase $\mathrm{Ca}$ uptake $(\mathrm{P}=0.07)$ despite the $1.4-10$-fold increase in $\mathrm{Ca}$ uptake. Earlier reports implicated SOCs in the influx of metals across the BBB. Lead uptake into bBMECs was increased by 1.7- and 2.1-fold following treatment with CPA or thapsigargin, respectively (Kerper and Hinkle, 1997b). The pH dependence of $\mathrm{Mn}$ uptake is also consistent with a role for SOCs in Mn influx at the BBB. Storeoperated Ca influx was inhibited by low extracellular pH in human microglia (Khoo et al., 2001). These results suggest that brain Mn uptake occurs through the SOCs. 
In summary, there are at least two transporters for brain $\mathrm{Mn}$ influx. Mn entry into brain occurs through at least one pathway that does not have a high affinity for $\mathrm{Ca}$, as evidenced with the $\mathrm{La}^{3+}$ data. Mn influx also is likely to occur through a $\mathrm{Ni}$ blocked, CPA-induced Ca pathway, which is consistent with store-operated $\mathrm{Ca}$ channels. 


\section{REFERENCES}

Allen DD, Smith QR. Characterization of the blood-brain barrier choline transporter using the in situ rat brain perfusion technique. J Neurochem 2001; 76(4): 1032-1041

Aschner M, Aschner JL. Manganese transport across the blood-brain barrier: relationship to iron homeostasis. Brain Res Bull 1990; 24(6): 857-860

Aschner M, Gannon M. Manganese (Mn) transport across the rat blood-brain barrier: saturable and transferrin-dependent transport mechanisms. Brain Res Bull 1994; 33(3): 345-349

Aschner M, Gannon M, Kimelberg HK. Manganese uptake and efflux in cultured rat astrocytes. J Neurochem 1992; 58(2): 730-735

Audus KL, Ng L, Wang W, Borchardt RT. Brain microvessel endothelial cell culture systems. In: Models for Assessing Drug Absorption and Metabolism, Ronald T. Borchardt Ea, Eds., ed., New York, Plenum Press, 1996, 239-258

Baldi C, Vazquez G, Boland R. Characterization of a 1,25(OH)2-vitamin D3responsive capacitative $\mathrm{Ca} 2+$ entry pathway in rat osteoblast-like cells. J Cell Biochem 2002; 86(4): 678-687

Bossu JL, Elhamdani A, Feltz A, Tanzi F, Aunis D, Thierse D. Voltage-gated Ca entry in isolated bovine capillary endothelial cells: evidence of a new type of BAY K 8644-sensitive channel. Pflugers Arch 1992; 420(2): 200-207

Bowman PD, Ennis SR, Rarey KE, Betz AL, Goldstein GW. Brain microvessel endothelial cells in tissue culture: a model for study of blood-brain barrier permeability. Ann Neurol 1983; 14(4): 396-402 
Chandra SV, Shukla GS, Srivastava RS, Singh H, Gupta VP. An exploratory study of manganese exposure to welders. Clin Toxicol 1981; 18(4): 407-416

Conrad ME, Umbreit JN, Moore EG, Hainsworth LN, Porubcin M, Simovich MJ, Nakada MT, Dolan K, Garrick MD. Separate pathways for cellular uptake of ferric and ferrous iron. Am J Physiol Gastrointest Liver Physiol 2000; 279(4): G767-774

Couper J. On the effects of black oxide of manganese when inhaled into the lungs. Brit Ann Med Pharm, Vital Stat Gen Sci 1837; 1: 41-42

Crossgrove J, Yokel R. Manganese distribution across the blood-brain barrier III; The divalent metal transporter-1 is not the major mechanism mediating brain manganese uptake. NeuroToxicol 2004; 25(3): 451-460

Crossgrove JS, Allen DD, Bukaveckas BL, Rhineheimer SS, Yokel RA. Manganese distribution across the blood-brain barrier I. Evidence for carrier-mediated influx of manganese citrate as well as manganese and manganese transferrin. NeuroToxicol 2003; 24(1): 3-13

Cui ZJ, Dannies PS. Thyrotropin-releasing hormone-mediated Mn2+ entry in perifused rat anterior pituitary cells. Biochem J 1992; 283 ( Pt 2): 507-513

Davidson RM, Guo L. Calcium channel current in rat dental pulp cells. J Membr Biol $2000 ; 178(1): 21-3$

Dobrydneva Y, Blackmore P. 2-Aminoethoxydiphenyl borate directly inhibits storeoperated calcium entry channels in human platelets. Mol Pharmacol 2001; 60(3): $541-552$ 
Edlund GL, Halestrap AP. The kinetics of transport of lactate and pyruvate into rat hepatocytes. Evidence for the presence of a specific carrier similar to that in erythrocytes. Biochem J 1988; 249(1): 117-126

Fasolato C, Hoth M, Penner R. Multiple mechanisms of manganese-induced quenching of fura-2 fluorescence in rat mast cells. Pflugers Arch 1993; 423(34): $225-231$

Finley JW. Manganese uptake and release by cultured human hepato-carcinoma (Hep-G2) cells. Biol Trace Elem Res 1998; 64(1-3): 101-118

Goddard WP, Coupland K, Smith JA, Long RG. Iron uptake by isolated human enterocyte suspensions in vitro is dependent on body iron stores and inhibited by other metal cations. J Nutr 1997; 127(1): 177-183

Grundemann D, Hahne C, Berkels R, Schomig E. Agmatine is efficiently transported by non-neuronal monoamine transporters extraneuronal monoamine transporter (EMT) and organic cation transporter 2 (OCT2). J Pharmacol Exp Ther 2003; 304(2): 810-817

Gunshin H, Mackenzie B, Berger UV, Gunshin Y, Romero MF, Boron WF, Nussberger S, Gollan JL, Hediger MA. Cloning and characterization of a mammalian proton-coupled metal-ion transporter. Nature 1997; 388(6641): $482-488$

Huang CC, Chu NS, Lu CS, Wang JD, Tsai JL, Tzeng JL, Wolters EC, Calne DB. Chronic manganese intoxication. Arch Neurol 1989; 46(10): 1104-1106 
BBB Mn influx through SOCs 28

Hudnell HK. Effects from environmental Mn exposures: a review of the evidence from non-occupational exposure studies. NeuroToxicol 1999; 20(2-3): 379397

Iregren A. Manganese neurotoxicity in industrial exposures: proof of effects, critical exposure level, and sensitive tests. NeuroToxicol 1999; 20(2-3): 315-323

Jones KT, Sharpe GR. Ni2+ blocks the Ca2+ influx in human keratinocytes following a rise in extracellular Ca2+. Exp Cell Res 1994; 212(2): 409-413

Keen CL, Ensunsa JL, Clegg MS. Manganese metabolism in animals and humans including the toxicity of manganese. In: Manganese and its role in biological processes, Sigel A and Sigel H, ed., New York, Marcel Dekker, Inc., 2000, $89-121$

Keen CL, Lönnerdal B. Toxicity of essential and beneficial metal ions. Manganese. In: Handbook of Metal-Ligand Interactions in Biological Fluids, Berthon G, ed., New York, NY, Marcel Dekker, Inc., 1995, 683-688

Keep RF, Ulanski LJ, 2nd, Xiang J, Ennis SR, Lorris Betz A. Blood-brain barrier mechanisms involved in brain calcium and potassium homeostasis. Brain Res 1999; 815(2): 200-205

Kerper LE, Hinkle PM. Cellular uptake of lead is activated by depletion of intracellular calcium stores. J Biol Chem 1997a; 272(13): 8346-8352

Kerper LE, Hinkle PM. Lead uptake in brain capillary endothelial cells: activation by calcium store depletion. Toxicol Appl Pharmacol 1997b; 146(1): 127-133 
Khoo C, Helm J, Choi HB, Kim SU, McLarnon JG. Inhibition of store-operated $\mathrm{Ca}(2+)$ influx by acidic extracellular $\mathrm{pH}$ in cultured human microglia. Glia $2001 ; 36(1): 22-30$

Kim YV, Di Cello F, Hillaire CS, Kim KS. Differential $\mathrm{Ca}^{2+}$ signaling by thrombin and protease-activated receptor-1-activating peptide in human brain microvascular endothelial cells. Am J Physiol Cell Physiol 2004; 286(1):C3142

Klaassen CD. Biliary excretion of manganese in rats, rabbits, and dogs. Toxicol Appl Pharmacol 1974; 29(3): 458-468

Kondakis XG, Makris N, Leotsinidis M, Prinou M, Papapetropoulos T. Possible health effects of high manganese concentration in drinking water. Arch Environ Health 1989; 44(3): 175-178

Kukkonen JP, Lund PE, Akerman KE. 2-aminoethoxydiphenyl borate reveals heterogeneity in receptor-activated $\mathrm{Ca}(2+)$ discharge and store-operated $\mathrm{Ca}(2+)$ influx. Cell Calcium 2001; 30(2): 117-129

Lee J-W. Manganese Intoxication. Arch Neurol 2000; 57(4): 597-599

Liu X, Ambudkar IS. Characteristics of a store-operated calcium-permeable channel: sarcoendoplasmic reticulum calcium pump function controls channel gating. $J$ Biol Chem 2001; 276(32): 29891-29898

Lockman PR, Roder KE, Allen DD. Inhibition of the rat blood-brain barrier choline transporter by manganese chloride. J Neurochem 2001; 79(3): 588-594 Manoonkitiwongsa PS, Whitter EF, Wareesangtip W, McMillan PJ, Nava PB, Schultz RL. Calcium-dependent ATPase unlike ecto-ATPase is located primarily on 
BBB Mn influx through SOCs 30

the luminal surface of brain endothelial cells. Histochem J 2000; 32(5): 31324

Mason MJ, Mayer B, Hymel LJ. Inhibition of Ca2+ transport pathways in thymic lymphocytes by econazole, miconazole, and SKF 96365. Am J Physiol 1993; 264(3 Pt 1): C654-662

Murphy VA, Smith QR, Rapoport SI. Uptake and concentrations of calcium in rat choroid plexus during chronic hypo- and hypercalcemia. Brain Res 1989; 484(1-2): $65-70$

Murphy VA, Wadhwani KC, Smith QR, Rapoport SI. Saturable transport of manganese(II) across the rat blood-brain barrier. J Neurochem 1991; 57(3): 948-954

Ono K, Komai K, Yamada M. Myoclonic involuntary movement associated with chronic manganese poisoning. J Neurol Sci 2002; 199(1-2): 93-96

Poole RC, Halestrap AP, Price SJ, Levi AJ. The kinetics of transport of lactate and pyruvate into isolated cardiac myocytes from guinea pig. Kinetic evidence for the presence of a carrier distinct from that in erythrocytes and hepatocytes. Biochem J 1989; 264(2): 409-418

Rabin O, Hegedus L, Bourre JM, Smith QR. Rapid brain uptake of manganese (II) across the blood-brain barrier. $J$ Neurochem 1993; 61: 509-517

Schuttert JB, Fiedler GM, Grupp C, Blaschke S, Grunewald RW. Sorbitol transport in rat renal inner medullary interstitial cells. Kidney Int 2002; 61(4): 1407-1415 Shibuya I, Douglas WW. Calcium channels in rat melanotrophs are permeable to manganese, cobalt, cadmium, and lanthanum, but not to nickel: evidence 
provided by fluorescence changes in fura-2-loaded cells. Endocrinol 1992; 131(4): 1936-1941

Wedler FC, Denman RB. Glutamine synthetase: the major Mn(II) enzyme in mammalian brain. Curr Top Cell Reg 1984; 24: 153-169

Wu S, Sangerman J, Li M, Brough GH, Goodman SR, Stevens T. Essential control of an endothelial cell ISOC by the spectrin membrane skeleton. J Cell Biol $2001 ; 154(6): 1225-1233$

Xiao C, Cant JP. The glucose transporter in bovine mammary epithelial cells is an asymmetric carrier that exhibits cooperativity and trans-stimulation. $\mathrm{Am} \mathrm{J}$ Physiol Cell Physiol 2003; 285(5): C1226-1234

Yamakami J, Sakurai E, Sakurada T, Maeda K, Hikichi N. Stereoselective bloodbrain barrier transport of histidine in rats. Brain Res 1998; 812(1-2): 105-112

Yokel R, Wilson M, Harris W, Halestrap A. Aluminum citrate uptake by immortalized brain endothelial cells: Implications for its blood-brain barrier transport. Brain Res 2002; 930(1-2): 101-110

Yokel RA, Crossgrove JS, Bukaveckas BL. Manganese distribution across the blood-brain barrier II. Manganese efflux from the brain does not appear to be carrier mediated. NeuroToxicol 2003; 24(1): 15-22 
Table 1. Characteristics of ${ }^{54} \mathrm{Mn}^{2+}$ uptake into bBMECs

\begin{tabular}{|c|c|c|}
\hline Treatment & $\begin{array}{c}\text { Mn uptake } \\
\text { (\% control } \pm \text { SEM) }\end{array}$ & $\mathbf{n}$ \\
\hline Control (122 mM Na+) & $100 \pm 7$ & 6 \\
\hline $61 \mathrm{mM} \mathrm{Na}^{+}, 61 \mathrm{mM}$ choline & $97 \pm 18$ & 3 \\
\hline 122 mM\% Choline (no Na+) & $160 \pm 6^{*}$ & 5 \\
\hline $122 \mathrm{mM} \mathrm{Li}^{+}\left(\mathrm{no} \mathrm{Na}^{+}\right)$ & $90 \pm 9$ & 4 \\
\hline Control (vehicle) & $100 \pm 10$ & 3 \\
\hline Ouabain & $129 \pm 15$ & 3 \\
\hline Control (vehicle) & $100 \pm 6$ & 8 \\
\hline 2,4-Dinitrophenol & $102 \pm 5$ & 6 \\
\hline Azide & $124 \pm 4$ & 3 \\
\hline 2-Deoxyglucose & $84 \pm 8$ & 4 \\
\hline
\end{tabular}

${ }^{*}=$ significantly different from control. 
Table 2. Mn and Ca uptake into bBMECs in the presence of Ca transporter inhibitors

\begin{tabular}{|c|c|c|c|}
\hline Treatment & $\begin{array}{c}\text { Ca uptake } \\
(\% \text { control } \pm \text { SEM })\end{array}$ & $\begin{array}{c}\text { Mn uptake } \\
(\% \text { control } \pm \text { SEM })\end{array}$ & $\mathbf{N}$ \\
\hline Control & & $100 \pm 18$ & 5 \\
\hline No $\mathrm{Ca}^{2+}$ & & $170 \pm 29^{*}$ & 4 \\
\hline \multicolumn{2}{|l|}{ Control } & $100 \pm 5$ & 4 \\
\hline \multicolumn{2}{|c|}{ Vanadate $(0.003 \mu \mathrm{M})$} & $64 \pm 3^{*}$ & 3 \\
\hline \multicolumn{2}{|c|}{ Vanadate $(1 \mathrm{mM})$} & $53 \pm 4^{*}$ & 3 \\
\hline \multicolumn{2}{|c|}{ Vanadate pretreatment $(1 \mathrm{mM})$} & $39 \pm 4^{*}$ & 3 \\
\hline Control & $100 \pm 17$ & $100 \pm 8$ & 4 \\
\hline $\mathrm{La}^{3+}$ & $58 \pm 25^{*}$ & $64 \pm 24$ & 4 \\
\hline $\mathrm{Ni}^{2+}$ & $15 \pm 15^{*}$ & $12 \pm 3^{*}$ & 3 \\
\hline Verapamil & $54 \pm 3$ & $81 \pm 2$ & 3 \\
\hline Control (vehicle) & $100 \pm 30$ & $100 \pm 13$ & 3 \\
\hline CPA & $418 \pm 98^{*}$ & $265 \pm 48^{*}$ & 4 \\
\hline Thapsigargin & $415 \pm 212$ & $252 \pm 23^{*}$ & 4 \\
\hline
\end{tabular}


Figure 1. Mn uptake into bBMECs correlates inversely with proton concentration. Values are mean percent of control $(\mathrm{pH} 7.4)$ uptake \pm SEM for 3-6 experiments, following 30 minute incubation. Inset: Time dependent uptake of $\mathrm{Mn}$ at $\mathrm{pH} 6.4$ versus 7.4 is shown. ${ }^{*}$ denotes a significant difference from control

Figure 2. The Arrhenius plot shows temperature-dependent Mn uptake into bBMECs. Values shown are the natural log of the mean \pm SEM of uptake $(p m o l / 30$ $\min / \mathrm{mg})$.

Figure 3. Mn influx correlates negatively with Ca concentration following in situ perfusion, but Mn concentration has no effect on $\mathrm{Ca}$ influx. A) $\mathrm{Mn}$ and B) Ca influx values into brain are shown (mean \pm SEM of $4-5$ animals).

Figure 4. La increased Mn influx into rat brain. Values shown are mean \pm SEM $(n=5)$. The $Y$-axis in panel A is different from previous $M n$ influx graphs.

Figure 5. Ni did not decrease Mn (A) influx into rat brain across the BBB. Values shown are mean \pm SEM $(n=5) .{ }^{*}$ significantly different from control 


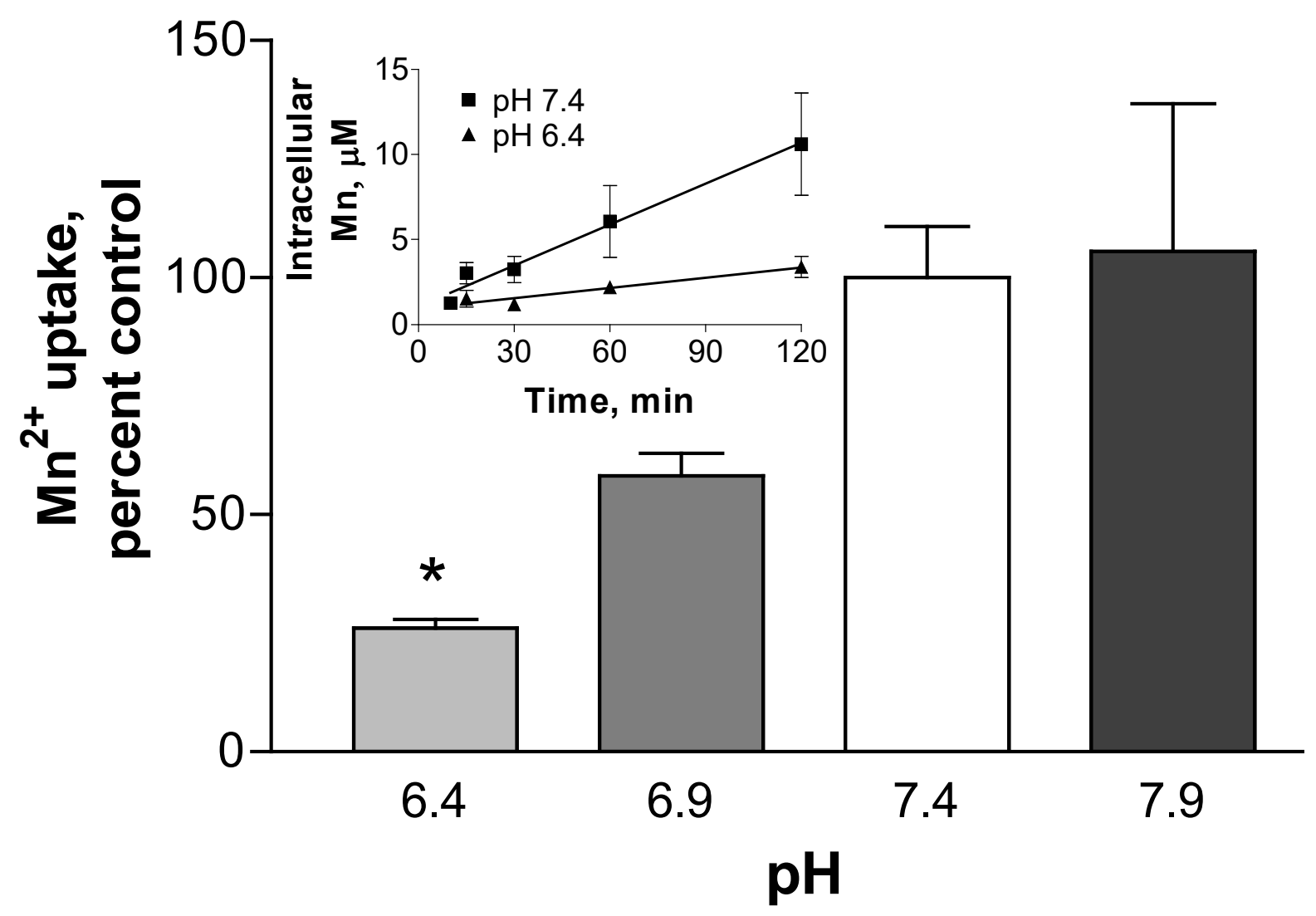

Figure 1 
BBB Mn influx through SOCs 36

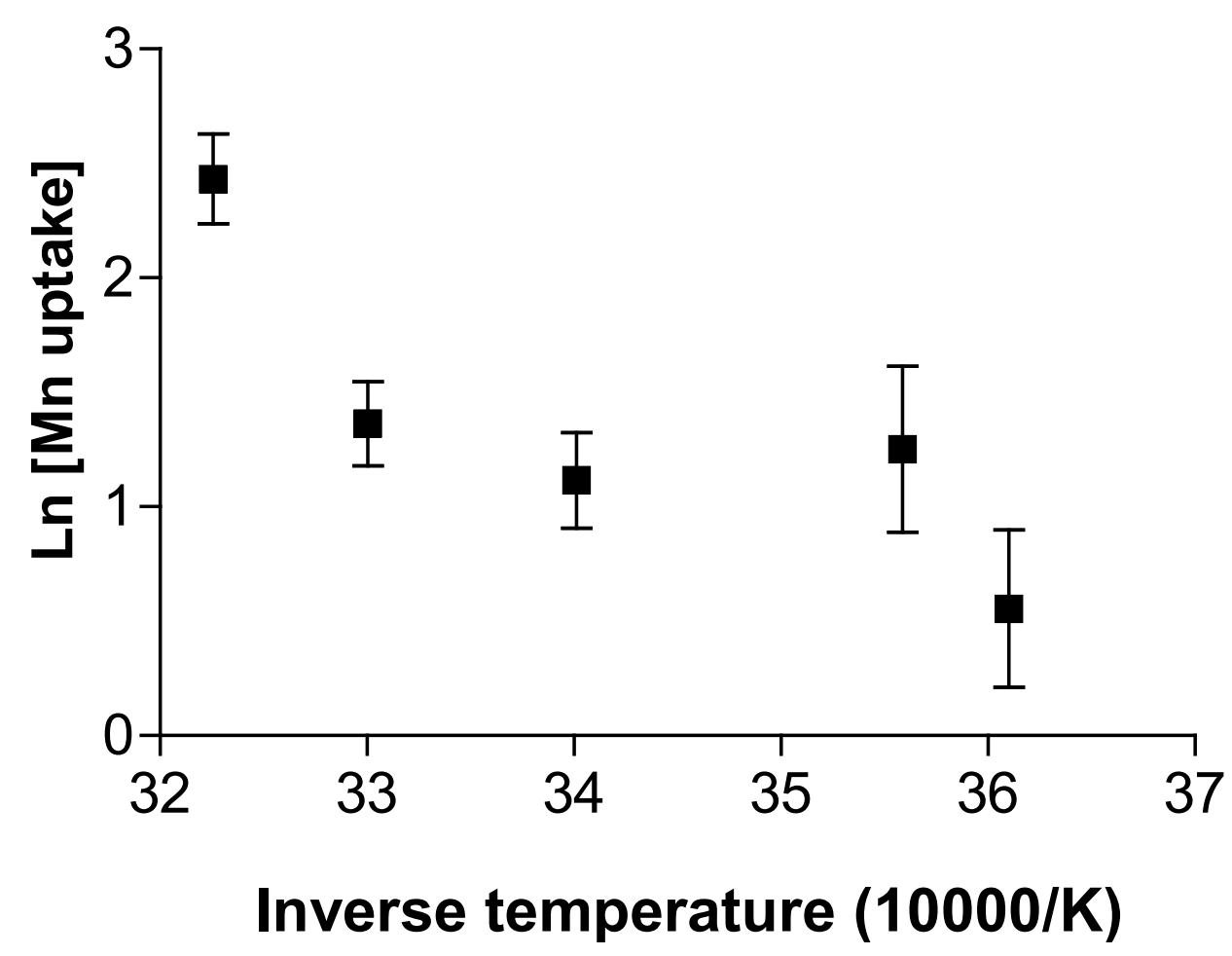

Figure 2 

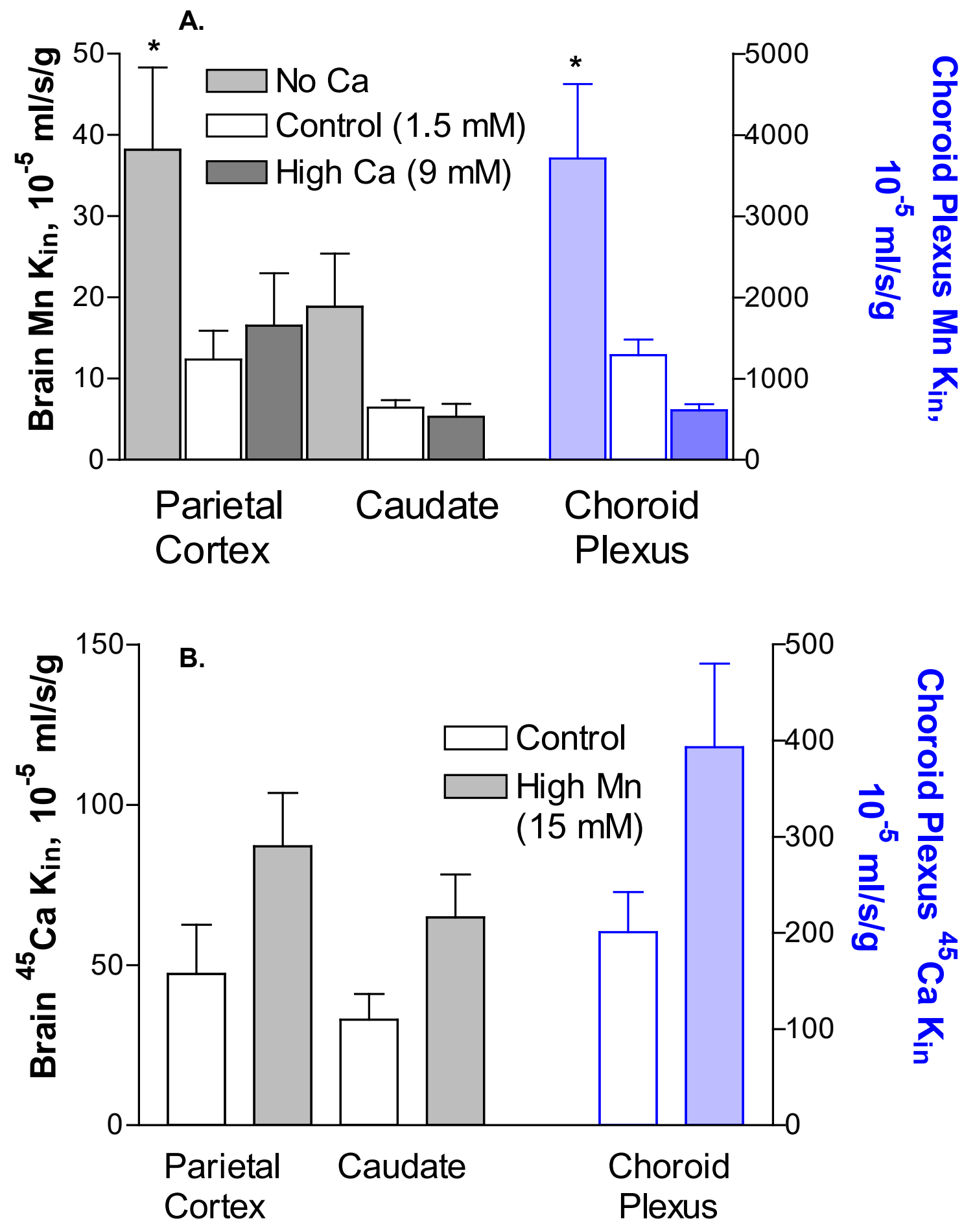

Figure 3 
BBB Mn influx through SOCs 38

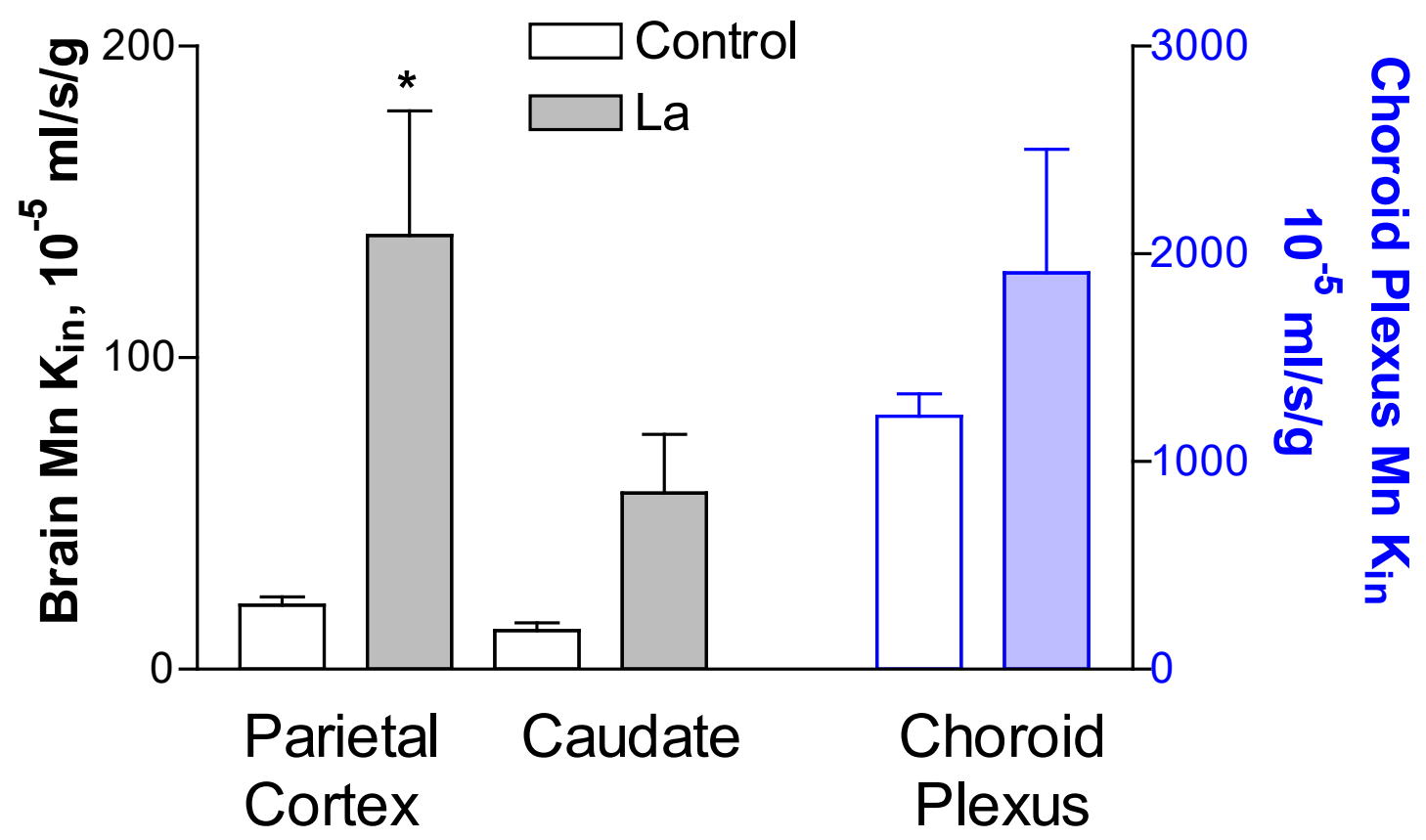

Figure 4 


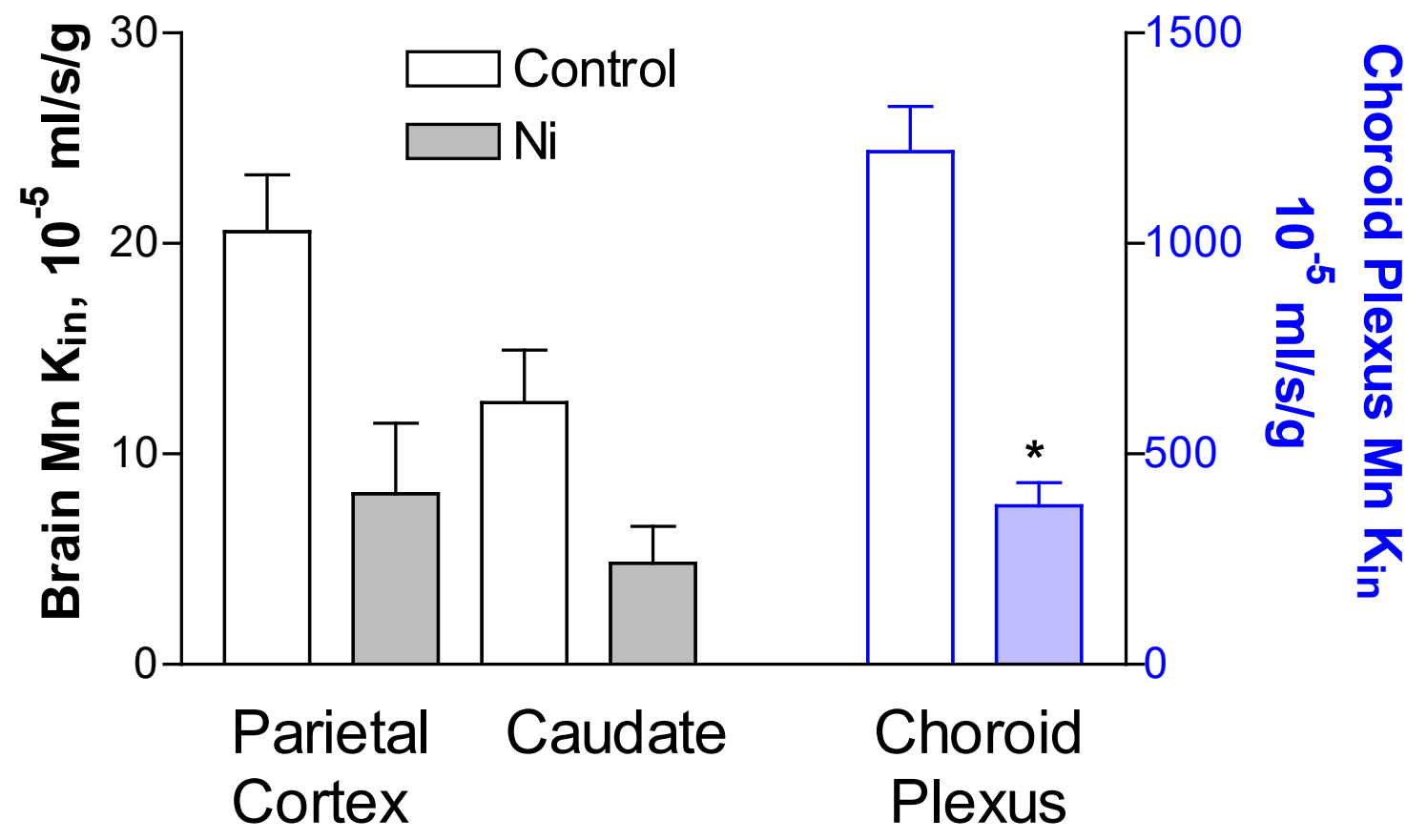

Figure 5 